\title{
Cover Crops as an Agroecological Practice on Organic Vegetable Farms in Wisconsin, USA
}

\author{
Erin M. Silva ${ }^{1,2, *}$ and Virginia M. Moore ${ }^{2,3}$ \\ 1 Department of Plant Pathology, University of Wisconsin-Madison, 1630 Linden Dr., Madison, WI 53706, USA \\ 2 Plant Breeding and Plant Genetics Program, University of Wisconsin-Madison, 1575 Linden Dr., Madison, \\ WI 53706, USA; vmmoore@wisc.edu \\ 3 Department of Agronomy, University of Wisconsin-Madison, 1575 Linden Dr., Madison, WI 53706, USA \\ * Correspondence: emsilva@wisc.edu; Tel.: +1-608-890-1503; Fax: +1-608-263-2626
}

Academic Editor: Carol Shennan

Received: 6 October 2016; Accepted: 14 December 2016; Published: 1 January 2017

\begin{abstract}
Global agricultural and food systems face the challenge of feeding a growing world population in the face of finite and diminishing resources. To guide the redesign of agricultural systems, farmers and policymakers are increasingly turning to agroecology. Organic agriculture has historically integrated agroecological practices within its regulatory framework; however, questions remain as to the extent to which organic farmers are maintaining and expanding agroecological practices. In this paper, we will address convergences and divergences of agroecological and organic practices. Using cover cropping as a model agroecological practice, we conduct a preliminary assessment on the degree to which organic vegetable farms in Wisconsin, USA are integrating agroecological concepts into their farm management, drawing upon the results of a 2013 cover cropping practice survey. The survey data demonstrates varying degrees of complexity and diversity in cover cropping practices, potentially illustrating the desire of organic farmers to promote a high degree of agroecosystem services. Farmers' integration of cover crop diversity and complexity was not correlated to farm size or revenue. These results offer preliminary evidence that Wisconsin's organic vegetable farmers are integrating agroecological practices on their farms, even as growth in the organic market continues to occur.
\end{abstract}

Keywords: agroecology; organic agriculture; cover cropping; ecosystem services; USA

\section{Introduction}

Our global agricultural and food systems face the challenge of feeding a growing world population in the face of finite and diminishing resources. As we look toward the issues confronting farmers-soil erosion, ground and surface water contamination, chemical-resistant weeds and insects, diminishing fossil fuel-derived and mined resources-it becomes clear that in order to achieve a sustainable path forward, our future agricultural systems must be based on adaptable practices which enhance the cycling resources and ecological balance, while maintaining productive, nutritionally-dense crops.

To guide the redesign of agricultural systems on which the global food supply depends, farmers and policymakers are increasingly turning to agroecology. Agroecology, the integration of ecological concepts to agricultural systems, arose in the early part of the 20th century as a response to the increasing industrialization of our agricultural system [1,2]. One broadly-used definition describes agroecology as "... the integrative study of the ecology of the entire food system, encompassing ecological, economic and social dimensions" [3]. As a set of farming practices, agroecology promotes more ecological strategies of management, including less dependence on monoculture systems; avoidance of input substitution, external input markets, and costly biotechnology packages; cycling of 
resources on-farm or from local agroecosystem territories; protection of environment; and emphasis on local or regional market structures and territorial development strategies [4].

As with agroecology, the term "organic agriculture" has been used to describe a specific agricultural production system for almost a century. Lampkin (1990) defines organic agriculture as a farming system approach that aims "to create integrated, humane, environmentally and economically sustainable production systems, which maximize reliance on farm-derived renewable resources and the management of ecological and biological processes and interactions, so as to provide acceptable levels of crop, livestock and human nutrition, protection from pests and disease, and an appropriate return to the human and other resources" [5]. Another definition has been offered by the International Federation of Agricultural Movements (IFOAM): "Organic Agriculture is a production system that sustains the health of soils, ecosystems and people. It relies on ecological processes, biodiversity and cycles adapted to local conditions, rather than the use of inputs with adverse effects. Organic agriculture combines tradition, innovation and science to benefit the shared environment and promote fair relationships and a good quality of life for all involved" [6].

Questions remain, however, as to the degree to which organic agriculture, with foundations grounded within ecological processes, aligns with agroecological production approaches. To begin to derive an answer to this question, we address convergences and divergences of agroecological and organic practices, focusing on the integration of agroecological perspectives into the United States Department of Agriculture's National Organic Program (USDA-NOP) regulation. Then, we will describe cover cropping as a model agroecological practice that is currently employed in varying degrees and complexities on organic farms across the United States of America (USA). As a case study, we will use cover cropping as an indicator with which to conduct a preliminary assessment on the integration of agroecological concepts into farm management on organic vegetable farms in Wisconsin, USA.

\section{Historical Overview of Agroecology and Organic Agriculture}

Differences in the genesis of agroecology and organic agriculture have led to differences in practical approaches that still remain today. Agroecology, while first noted by scientists and writers in the early part of the 20th century [1,7], gained strength in the middle part of the 20th century in response to environmental advocates' opposition to the industrialization of global agricultural systems and its increasingly apparent negative impacts on the greater ecosystem. In tandem to the recognition of agroecology as an agricultural approach throughout the twentieth century, organic agriculture achieved more widespread recognition. Unlike the term agroecology, which from the beginning had closer ties to the field of ecology, the origins of organic agriculture are more strongly aligned with soil enhancement and preservation. While mirroring the complexity of ecology in many respects, the school of thought which shaped organic agriculture was rooted in the philosophy of holism, in which the farm was viewed as a complex system (an "organism"), driven by processes that linked soil organic matter (referred to as "humus") and soil biology to crop, human, and livestock health [8,9].

While these two terms are used distinctly, commonalities do exist between organic farming and agroecology in both practice and vision. In terms of historic context, both were energized by the public response to intensive chemical pollution-in agriculture and in other industries-and the renewed discussions of environmentalism that had further turned to food and farming [10]. Both movements were energized by the publication of Rachel Carson's seminal work "Silent Spring" (1962), highlighting the dangers of pesticides in our food systems and environment. Finally, both promoted closed systems and resource cycling, diverse production approaches within a farming enterprise, diverse landscape elements, and reliance on biological processes for building soil fertility and controlling pests and diseases [11]. While the terms "agroecology" and "organic agriculture" have existed in agricultural lexicon for almost a century, the term "organic agriculture" is more highly recognized by consumers, in large part due to the regulatory and market component associated with organic agriculture in the USA and globally. 
Unlike organic agriculture, which is governed by strict regulatory codes, agroecology is not strictly defined by a codified set of practices. However, broad definitions do exist that allow for designation of certain practices as agroecological. According to Wezel et al. [12], "agroecological practices can be characterized as agricultural practices aiming to produce significant amounts of food, which seek to valorize ecological processes and ecosystem services by integrating them as fundamental elements in the development of the said practices, as opposed to simply relying on external inputs such as chemical fertilizer and synthetic pesticide application, or on technological solutions such as genetically modified organisms". As such, agroecological practices are based on various ecological processes and ecosystem services such as nutrient cycling, biological $\mathrm{N}$ fixation, natural regulation of pests, soil and water conservation, biodiversity conservation, and carbon sequestration, while contributing to the sustainability of the agricultural system [12]. Examples of agroecological practices include the use of cover crops, green manures, intercropping, agroforestry, biological control, resource and biodiversity conservation practices, or livestock integration $[2,12,13]$.

As the practices to be mandated by the USDA-NOP were established, alignment with agroecological practices is evident. The broad definition included in the USDA-NOP regulation describes organic production as a "production system that is managed in accordance with the Act and regulations in this part to respond to site-specific conditions by integrating cultural, biological, and mechanical practices that foster cycling of resources, promote ecological balance, and conserve biodiversity" [14]. The regulation specifically mentions practices that can be considered agroecological, including the use of crop rotation, cover crops, and catch crops to provide for pest management in annual and perennial crops (subpart $\S 205.206$ ), as well as cultural practices that enhance crop health, including selection of plant species and varieties with regard to suitability to site-specific conditions and resistance to prevalent pests, weeds, and diseases (subpart $\S 205.206$ ). Further, the organic regulation incorporates landscape elements of agroecology management, including the regulation of pest insects through the development of habitat for natural enemies of pests ( $\S 205.206)$.

\section{Cover Crops: An Indicator Agroecological Practice within Organic Management}

As the organic market expands and appetites for organic products increase, more hectares of land are being transitioned to certified organic management to capture market demand and access the higher prices that organic markets provide. With this transition of hectares, certified organic land may depart from the small, diversified and integrated farms historically typifying organic agriculture, with their use of more complex agroecological practices, and move toward larger, more specialized farms, mirroring the monocultures of conventional agriculture and their associated reliance on outside inputs. This phenomenon, referred to as "conventionalization", was first forwarded by Buck et al. in 1997 [15] to describe the California organic industry, as well as by Hall and Mogyorody in 2001 [16] in their assessment of the industry in Ontario, Canada. Buck et al. [15] contend that conventionalization can be demonstrated by certain farmer characteristics, practices, and orientations among larger organic farmers, in particular, the larger farmers who have recently moved to organic farming.

Almost 15 years after the inception of the USDA-NOP, few studies have demonstrated if conventionalization of the organic industry has truly occurred. In part, this is due to the difficulty in identifying specific agroecological practices that would be appropriate indicators to assess a wide range of organic farms across a wide regional distribution. As organic farming is not a "cookbook approach"-instead encouraging farmers to use appropriate strategies for their local climates and agroecosystems - the degree to which specific agroecological practices are implemented on farms will vary. Thus, it can be difficult to rigorously document, using a single or few indicators, the diversity of management practices employed on organic farms and their convergence or divergence with agroecological practices and principles.

One of the more widespread agroecological practices observed on organic farms, however, is cover cropping. Cover cropping can be described as the use of "vegetation planted or managed to protect and improve soil, crops, or water quality" [17]. Cover crops can provide numerous ecosystem services, 
including improving soil quality, nutrient cycling, pest regulation, and crop productivity, both in the same field, and also across time [18-21]. Thus, integrating cover crops into crop rotational strategies adds important foundational elements of agroecological management, including increasing diversity across multiple measures such as temporal, taxonomic, and functional biodiversity [22].

Many studies have documented the specific agroecological functions and impacts of cover crops, often in a more linear versus systems-based context. A subset of these studies are outlined in Table 1, organized by the agroecosystem service on which the research is focused. Many of the cover crops described in this table are commonly used over wide geographic regions, including Wisconsin, USA. Benefits conferred by cover crops are often multi-functional, simultaneously providing both agronomic and environmental; for example, increasing water infiltration also minimizes surface erosion, increasing water quality in surface waters. The complex nature of cover crop highlights a challenge in neatly categorizing their functional roles as agroecological practices, as agroecological performance does not necessarily depend on specific species or techniques, but is linked to processes that benefit the whole system [23].

Table 1. Examples of agroecosystem services provided by cover crops, as documented from peer-reviewed research studies.

\begin{tabular}{|c|c|c|c|c|}
\hline $\begin{array}{l}\text { Agroecosystem } \\
\text { Service }\end{array}$ & Cover Crop & Cash Crop System & Study Location & Citation \\
\hline \multirow{4}{*}{$\begin{array}{l}\text { Reduce soil } \\
\text { compaction }\end{array}$} & Forage radish (Raphanus sativus) & Not specified & Denmark & [24] \\
\hline & $\begin{array}{l}\text { Hairy vetch (Vicia villosa), sunnhemp } \\
\text { (Crotalaria juncea), soybeans (Glycine max) }\end{array}$ & $\begin{array}{c}\text { Winter wheat } \\
\text { (Triticum aestivum) and grain } \\
\text { sorghum (Sorghum bicolor) }\end{array}$ & Kansas, USA & [25] \\
\hline & $\begin{array}{l}\text { Forage radish; rapeseed (Brassica napus); } \\
\text { cereal rye (Secale cereale) }\end{array}$ & Maize (Zea mays) & Maryland, USA & [26] \\
\hline & $\begin{array}{l}\text { Millet (Pennisetum glaucum); sorghum; } \\
\text { and sunn hemp }\end{array}$ & Soybean & $\begin{array}{l}\text { Sao Paulo, } \\
\text { Brazil }\end{array}$ & [27] \\
\hline \multirow{3}{*}{$\begin{array}{l}\text { Improve soil } \\
\text { structure }\end{array}$} & Hairy vetch; sunnhemp; soybean & $\begin{array}{l}\text { Winter wheat and } \\
\text { grain sorghum }\end{array}$ & Kansas, USA & [25] \\
\hline & $\begin{array}{l}\text { Calopo (Calopogonio muconoides), sunn } \\
\text { hemp, sorghum, pigeon pea } \\
\text { (Cajanus cajan) and jack bean } \\
\text { (Canavalia ensiformis) with sorghum }\end{array}$ & Papaya (Carica papaya) & Bahia, Brazil & [28] \\
\hline & $\begin{array}{l}\text { Spring barley (Hordeum vulgare), } \\
\text { cereal rye, and annual ryegrass } \\
\text { (Lolium multiflorum) }\end{array}$ & Not specified & $\begin{array}{l}\text { British } \\
\text { Columbia, } \\
\text { Canada }\end{array}$ & [29] \\
\hline \multirow{3}{*}{$\begin{array}{l}\text { Improve water } \\
\text { infiltration }\end{array}$} & Black oat (Avena strigose) & $\begin{array}{c}\text { Tomato } \\
\text { (Solanum lycopersicum) }\end{array}$ & Uraguay & [30] \\
\hline & Winter wheat & Silage maize & California, USA & [31] \\
\hline & $\begin{array}{l}\text { Bromegrass (Bromus inermis), resident } \\
\text { vegetation, and strawberry clover } \\
\text { (Trifolium fragiferum) }\end{array}$ & Not specified & California, USA & [32] \\
\hline \multirow{3}{*}{$\begin{array}{l}\text { Improve soil } \\
\text { moisture retention }\end{array}$} & Forage radish; rapeseed; cereal rye & Maize & Maryland, USA & [26] \\
\hline & $\begin{array}{c}\text { Cereal rye, winter barley } \\
\text { (Hordeum vulgare), triticale (x Triticosecale } \\
\text { spp.), hairy vetch, Austrian winter pea } \\
\text { (Pisum sativum) }\end{array}$ & Soybean & $\begin{array}{l}\text { Wisconsin, } \\
\text { USA }\end{array}$ & [33] \\
\hline & Cereal rye and hairy vetch & Maize & Illinois, USA & [34] \\
\hline \multirow{3}{*}{$\begin{array}{l}\text { Increase soil } \\
\text { organic matter and } \\
\text { soil carbon }\end{array}$} & $\begin{array}{l}\text { Cereal rye and hairy vetch, alone and } \\
\text { in mixtures }\end{array}$ & $\begin{array}{l}\text { Cotton (Gossypium hirsutum) } \\
\text { and sorghum } \\
\text { (Sorghum bicolor) }\end{array}$ & Georgia, USA & [35] \\
\hline & $\begin{array}{l}\text { Guinea grass (Panicum maximum), Congo } \\
\text { grass (Brachiaria ruziziensis), palisade } \\
\text { grass (Brachiaria brizantha), and pearl } \\
\text { millet (Pennisetum glaucum) }\end{array}$ & Rice (Oryza sativa) & $\begin{array}{l}\text { Santo Antônio } \\
\text { de Goiás, Brazil }\end{array}$ & [36] \\
\hline & $\begin{array}{l}\text { Cereal rye and hairy vetch, } \\
\text { rye/vetch combination }\end{array}$ & Maize & $\begin{array}{l}\text { Massachusetts, } \\
\text { USA }\end{array}$ & [37] \\
\hline
\end{tabular}


Table 1. Cont.

\begin{tabular}{|c|c|c|c|c|}
\hline $\begin{array}{l}\text { Agroecosystem } \\
\text { Service }\end{array}$ & Cover Crop & Cash Crop System & Study Location & Citation \\
\hline \multirow{3}{*}{$\begin{array}{l}\text { Enhance nitrogen } \\
\quad \text { fixation }\end{array}$} & Brown mustard (Brassica hirta) & Potato (Solanum tuberosum) & $\begin{array}{c}\text { Washington, } \\
\text { USA }\end{array}$ & [38] \\
\hline & Hairy vetch & Tomato & Maryland, USA & [39] \\
\hline & Hairy vetch, sunnhemp, soybeans & & & [25] \\
\hline \multirow[b]{3}{*}{$\begin{array}{l}\text { Increase microbial } \\
\text { activity }\end{array}$} & Oat and common vetch (Vicia sativa) & $\begin{array}{c}\text { Green beans } \\
\text { (Phaseolus vulgaris) }\end{array}$ & Oregon, USA & [40] \\
\hline & Hariy vetch and cereal rye & Tomato & Maryland, USA & [41] \\
\hline & $\begin{array}{c}\text { Oat; hairy vetch; winter canola } \\
\text { (Brassica napus); cover crop mixture } 1 \\
\text { (cowpea (Vigna sinensis, V. unguiculata), } \\
\text { winter pea (Pisum sativum), millet } \\
\text { (Pennisetum americanum), forage radish, } \\
\text { turnip (Brassica rapa); cover crop mixture } 2 \\
\text { (winter canola, forage oats/winter pea, } \\
\text { crimson (Trifolium incarnatum)/alsike clover } \\
\text { (Trifolium hybridum), field pea } \\
\text { (Pisum sativum)/timothy (Phleum pretense), } \\
\text { forage radish/field pea) }\end{array}$ & Wheat and oat & $\begin{array}{l}\text { South Dakota, } \\
\text { USA }\end{array}$ & [42] \\
\hline \multirow{3}{*}{ Reduce erosion } & $\begin{array}{c}\text { White mustard (Sinapis alba), phacelia } \\
\text { (Phacelia tanacetifoli), annual ryegrass } \\
\text { (Lolium perenne), oats, cereal rye, } \\
\text { forage radish }\end{array}$ & Not provided & Belgium & [43] \\
\hline & Cereal rye and oat & Corn-soybean rotation & Iowa, USA & [44] \\
\hline & Sunn hemp; sorghum sudangrass; oats & $\begin{array}{c}\text { Sugarcane } \\
\text { (Saccharum officinarum) }\end{array}$ & Hawaii, USA & [45] \\
\hline \multirow{4}{*}{$\begin{array}{l}\text { Reduce nutrient } \\
\text { leaching and loss }\end{array}$} & Cereal rye and oat & Corn-soybean rotation & Iowa, USA & [46] \\
\hline & Cereal rye & Lettuce (Latuca sativa) & California, USA & [47] \\
\hline & Phacelia and cereal rye & Broccoli (Brassica oleraceae) & California, USA & [48] \\
\hline & Meta-analysis & & & [18] \\
\hline \multirow{3}{*}{ Suppress weeds } & $\begin{array}{l}\text { Mustard (Sinapis alba), forage radish, and } \\
\text { spring vetch (Vicia sativa); mixture } 1 \text { (spring } \\
\text { vetch, forage radish, berseem clover } \\
\text { (Trifolium alexandrinum); mixture } 2 \text { (field } \\
\text { pea, lupin (Lupinus angustifolius), black oat } \\
\text { (Avena strigose) berseem clover, phacelia, } \\
\text { niger (Guizotia abyssinica) }\end{array}$ & - & Germany & [49] \\
\hline & $\begin{array}{l}\text { White mustard (Sinapis alba), oilseed radish, } \\
\text { phacelia, tartary buckwheat } \\
\text { (Fagopyrum tataricum), forage radish, } \\
\text { red oat (Avena byzantine), grain amaranth } \\
\text { (Amaranthus cruentus) }\end{array}$ & $\begin{array}{l}\text { Wheat and barley } \\
\text { (Hordeum vulgare) }\end{array}$ & Germany & [50] \\
\hline & $\begin{array}{l}\text { Mustard (Sinapis alba) and Indian mustard } \\
\text { (Brassica juncea) }\end{array}$ & Vegetables & $\begin{array}{c}\text { Illinois, } \\
\text { New York, and } \\
\text { Michigan, USA }\end{array}$ & [51] \\
\hline $\begin{array}{c}\text { Enhance pollinator } \\
\text { and beneficial } \\
\text { habitat }\end{array}$ & $\begin{array}{c}\text { Rapeseed, medium red clover } \\
\text { (Trifolium pratense), Austrian winter pea } \\
\text { (Pisum sativum subsp. arvense), and cereal } \\
\text { rye; and a six species mix that included } \\
\text { rapeseed, medium red clover Austrian } \\
\text { winter pea, cereal rye, forage radish } \\
\text { and oats }\end{array}$ & $\begin{array}{l}\text { Corn-soybean-winter } \\
\text { wheat rotation }\end{array}$ & $\begin{array}{l}\text { Pennsylvania, } \\
\text { USA }\end{array}$ & [52] \\
\hline \multirow{2}{*}{$\begin{array}{l}\text { Increase beneficial } \\
\text { insects }\end{array}$} & $\begin{array}{l}\text { Mustard (Brassica spp.) and buckwheat } \\
\text { (Fagopyrum esculentum) }\end{array}$ & Broccoli & California, USA & [53] \\
\hline & Tall fescue (Festuca arundinace) & $\begin{array}{l}\text { Clementine mandarin } \\
\text { (Citrus clementina) }\end{array}$ & Spain & [54] \\
\hline \multirow{3}{*}{$\begin{array}{l}\text { Suppress soil } \\
\text { disease and } \\
\text { nematodes }\end{array}$} & Sunnhemp and sorghum sudangrass & $\begin{array}{c}\text { Okra } \\
\text { (Abelmoschus esculentus) }\end{array}$ & Florida, USA & [55] \\
\hline & Sudangrass & Lettuce (Latuca sativa) & New York, USA & [56] \\
\hline & $\begin{array}{l}\text { Cowpea, sunnhemp, pearl millet, sorghum } \\
\text { sudangrass, alone and in a mixture }\end{array}$ & Tomato & Florida, USA & [57] \\
\hline
\end{tabular}


Several of the cover crop benefits outlined in Table 1 involve soil quality and health enhancement, including improvements to soil fertility, soil structure, and soil ecology. Cover crops sequester and store nutrients that might otherwise be lost to leaching or runoff, maintaining fertility within the system. In particular, densely-rooted cover crops scavenge nutrients from deep in the soil profile, providing fertility for future crops [58-60]. Leguminous cover crops fix nitrogen from the atmosphere, providing a source of fertility needed by subsequent cash crops, without reliance on outside inputs [58,59,61-64]. With the contribution of both above- and below-ground biomass, cover crops can increase soil organic matter, which in turn has the effect of improving soil structure and aggregation.

Cover crops also improve soil-hydrologic relationships such as infiltration, drainage, and aeration. Deep-rooted cover crops can penetrate and loosen subsurface compaction [58,59] and living vegetation and surface residues serve a protective role, minimizing erosion from wind and water $[58-60,62,65]$. Improvements in soil structure and reduced need for chemical inputs also both lead to reduced nutrient leaching, which can ultimately improve water quality [58,62,66-69]. When cover crop residues remain on the soil surface, additional hydrologic benefits may be incurred, such as reductions in runoff of sediment and nutrients and reduced irrigation needs due to lower evaporation $[59,69]$.

Cover crops are increasingly used by farmers as a systems-based pest management tool. Particularly when paired with high biomass reduced tillage systems, cover crops can be a highly effective weed control option for organic farmers, as demonstrated by cover crop-based reduced tillage systems $[33,58,59,61,62,70]$. Beyond high biomass reduced tillage systems, planted in rotation with cash crop production, cover crops provide weed suppression through resource competition [58], niche disruption through modification of light, soil temperature, and/or soil moisture [24,28], and allelopathy $[58,62,71]$. Cover crops can have positive or negative impacts on pest and disease problems, with certain cover and cash crop combinations (either simultaneously or sequentially) either attracting more pest insects, or conversely, more beneficial predators that reduce pest populations. Similarly, cover crops may disrupt a disease cycle or prevent disease from spreading, or serve as an alternate host for the pathogen $[58,59,61,62,71]$.

\section{Methods: Can Perspectives from Wisconsin's Organic Vegetable Farmers Help Gauge Their Agroecological Priorities?}

While the organic market continues to expand and price advantages are maintained, more farmers may be motivated to enter organic production. Depending on the route taken to increase their production-expanding hectares on an existing organic farm, or transitioning a conventional farm to certified organic-farmers will have different experiences, motivations, and perspectives. Additionally, they may experience varying pressures and opportunities that either persuade or dissuade the adoption of more complex and costly practices with multiple agroecological benefits. The attitudes of both new and existing organic farmers, including their prioritization of external environmental and societal goals as well as production goals, will be important determinants of the adoption of agroecological practices to the extent that farmer perceptions, beliefs, and values influence their decision-making. Influenced by psychological theory, the Reasoned Action Approach (RAA) [72] considers that a person's behavior depends on their intentions, which in turn depend on their attitudes, subjective norms, and the perceived ease or difficulty in controlling the behavior. Incorporation of perceptions and values into an agroecological practice adoption framework resonates with the holon theory of agroecology, which proposes the consideration of a farmer or other actor on the agricultural and food systems landscape as a holon, or an "intentional entity embedded in an ecology of contexts" [73]. As such, farmers make decisions based on a range of factors beyond simple agronomic or economic considerations, but rather their decisions to implement agroecological practices will be influenced by factors ranging from internal values to societal and landscape-scale interactions.

Wisconsin, with its strong, vibrant history in organic agriculture, provides a unique opportunity to assess trends in conventionalization of the industry—or, at a minimum, the adherence of organic farmers to the agroecological approaches that more closely align with the philosophy underpinning 
the organic regulation. Located in the upper Midwestern region, Wisconsin has long served as primary region of organic production in the USA (Figure 1). In 2001, Wisconsin ranked \#3 in total organic farms, behind California and Washington, with 469 organic operations [74]. A decade later, Wisconsin had risen to the \#2 ranking, with 1180 organic farms in total, and 161 vegetable farms certified organic [75]. Organic vegetable farmers throughout the state are extremely diverse in experience, size, markets, and crop diversity, ranging from beginning farmers to those with $30+$ years of experience, from 1 hectare to $100+$ hectare farms, and from those producing a handful of crops to farms producing over 30 different types of vegetables [76].

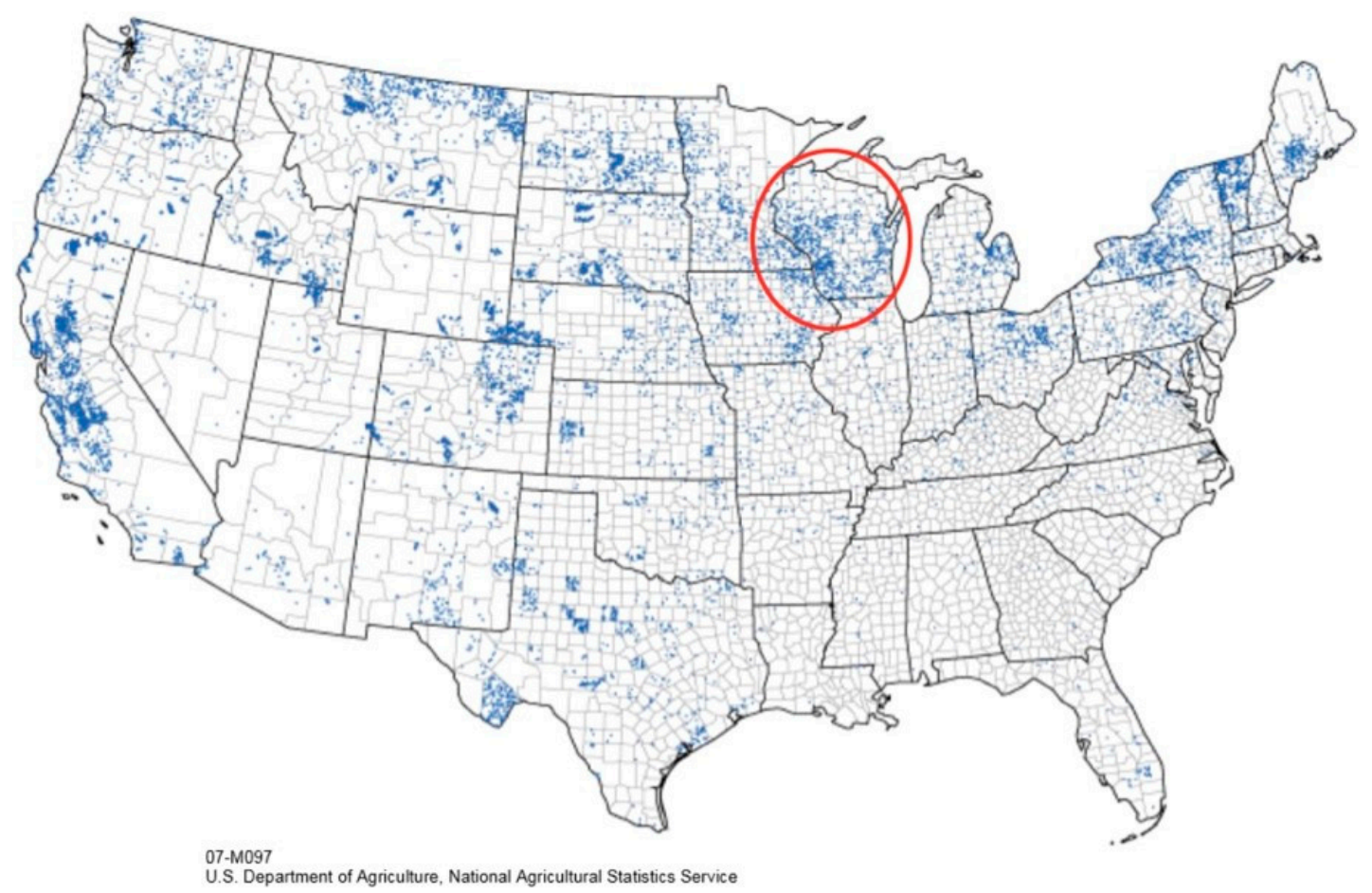

Figure 1. Location of Wisconsin, USA as highlighted by the red circle. Blue dots represent organic hectares in the USA as documented by the 2007 USDA Census of Agriculture, with one dot representing approximate 100 hectares (map obtained from the USDA National Agricultural Statistics Service).

To apply this approach to a preliminary investigation of the degree of adherence and commitment of Wisconsin's organic vegetable farmers to agroecological management approaches, we used cover cropping as a model indicator practice. The survey data used for this work was collected in 2014, in an effort to assess the cover cropping practices of Wisconsin's organic vegetable farmers in 2013 as well as in prior years of farming (more details on the survey design and summary of results can be found in Moore et al., 2016 [77]). This survey, intended to assess the extent, diversity, and complexity to which organic vegetable farmers were employing cover crops, was designed and distributed using the tailored design method [78]. The survey was mailed through the United States Postal Service to each of the 322 certified organic vegetable growers in the state of Wisconsin, using addresses acquired from the USDA-NOP. Farmers were contacted a total of five times, including three mailings of the survey questionnaire and two mailings of reminder postcards, between January and March 2014. A total of 152 completed surveys were returned, constituting a response rate of $47 \%$. Questions included cover crop use, related motivations and perceptions, and farm demographic information (size, number of years farming, education, among others). With this information, we were able derive cover cropping trends within this organic agricultural sector over time, as well as the agroecological goals of farmers using cover crops. 
To investigate the primary factors related to the farmers' use of cover crops to maximize agroecological function (as indicated by extent of cover crop use, cover crop diversity, and cover crop complexity), different econometric models and regression analyses were performed as determined by the type of dependent variable. The two-limit Tobit model was used to perform regressions to investigate explanatory variables related to the extent of cover crop adoption, with continuous variables representing the proportion of vegetable acres planted to cover crops for some part of the 2013 production season. The cover crop diversity regression was performed using negative binomial regression, with the dependent variable as the number of cover crop species. Lastly, as the indicator variables for complexity of cover crop use were binary and correlated (yes or no as to the use of two practices, underseeding and intercropping of cover crops with cash crops), a bivariate probit regression was used to determine related farm demographic factors. STATA 14.0 was used to estimate regressions, using the tobit command for the two-limit Tobit regression, the nbreg command for the negative binomial regression, and the biprobit command for the bivariate probit regression. More information on the specific regression approaches can be found in the more extensive summary of the survey results published by Moore et al. [77].

\section{Results}

Survey responses demonstrated that cover cropping was routinely integrated into organic vegetable farm management. Ninety-two percent of respondents had used cover crops at some point in their farming career, and 78\% planted them during 2013 [77]. Additionally, diverse portfolios of cover crops were used by respondents, including barley, buckwheat, clovers, cowpea, millet, mustards, oats, peas, cereal rye, annual ryegrass, sorghum sudangrass, tillage radish, turnip, hairy vetch, and winter wheat.

Results of the survey further indicated that cover cropping was increasing as a practice with the growth of organic vegetable farms in Wisconsin. A closer analysis of the respondents who used cover crops in a particular farming season shows an increasing utilization of this practice over the 20 years prior to the survey year (1983-2013), rising from a low of less than $10 \%$ of organic vegetable farmers using cover crops in 1983, to over $90 \%$ of organic vegetable farmers using this practice in 2013 [77]. On a given farm, the extent to which cover crops are planted on the land varies, from $25 \%$ of farmers planting none of their vegetable land in cover crops, $25 \%$ planting all of their vegetable land in cover crops, and the remaining farmers planting a portion of their vegetable land in cover crops.

In addition to the extent of cover crop adoption over years farming as an agroecological practices indicator, the complexity to which cover crops are managed can serve as another gauge as to the farmer's commitment to agroecological farming approaches. On the simplest level, if a farmer maintains their primary motivation to plant cover crops as adherence to the requirements of certification agencies, the most basic solution would be to plant a clean field in a single cover crop. However, more complicated strategies-underseeding into a cash crop, interplanting cover crops at the time of cash crop planting, using more complex mixtures and cover crop "cocktails"-speaks to the desire of the farmer to use cover crops with more multifunctional intentions. The Wisconsin survey results indicated that $25.7 \%$ of respondents under-seeded cover crops before the cash crop was harvested from the field, and $29.4 \%$ inter-planted cover crops in pathways between their cash crops [77]. Additionally, farmers planted multiple cover crop species both within single fields and across their farms, benefitting from the multiple agronomic and ecosystem service traits provide by different cover crop species. Results of the survey indicated that farmers integrated more than one cover crop species into their management plans, using an average of two species every year and three species at least in some years for a total average of five cover crop species used per farm [77]. Achieving even greater levels of complexity and diversity, a large number $(64.0 \%)$ of respondents planted cover crop species mixtures in some fields.

Survey respondents were also asked to rank the reasons why they used cover crops, given the options of the following agroecological functions: adding organic matter; improving fertility; 
improving soil structure; suppressing weeds; erosion protection; preventing nutrient leaching; reducing pests and diseases; increasing biodiversity/habitat; and improving water infiltration. Increasing soil organic matter had the most votes in the top 3 (97), with improving soil fertility ranking closely behind (90) [77]. A third soil function, improving soil structure, was the third highest factor ranking the top three (66). Other non-soil related agroecological functions, such as reducing pest and disease and increasing biodiversity and habitat, ranked much lower, with only six respondents ranking each in the top three.

Interestingly, these rankings did not conform closely with farmers' perceptions of cover crop benefits. Respondents were asked to respond to a series of statements on a five-point Likert scale, from "strongly agree", "agree", "neutral", "disagree", and "strongly disagree". Statements included: cover cropping improves farm profitability; cover cropping improves soil health, cover cropping improves soil fertility; cover cropping decreases weed and pest pressure; and cover cropping increases biodiversity/habitat. Most farmers most strongly agreed with statements about soil benefits: $98 \%$ of respondents agreed or strongly agreed that "cover cropping improves soil health", and 99\% agreed or strongly agreed that "cover cropping improves fertility" [77]. However, respondents also agreed (albeit less strongly) that cover crops offer other benefits ( $88 \%$ agreed or strongly agreed that "cover cropping decreases weed/pest problems", and $82 \%$ agreed or strongly agreed that "cover cropping increases biodiversity/habitat"). These values indicate that a significantly greater proportion of farmers held beliefs that broader agroecological benefits existed as compared to the number of farmers planting cover crops with the intention of deriving those ecosystem benefits. However, a significant number of farmers also felt that cover crops benefitted the economic aspects of sustainability on their farm, with $87 \%$ agreeing or strongly agreeing that "cover cropping improves farm profitability" [77].

Regression analyses demonstrated several relationships between cover crop adoption and farm characteristics. Cover cropping extent was found to be strongly correlated with the farm's dependence on vegetable revenue; the more dependent a farm was on revenue from vegetable crops, the smaller the proportion of vegetable hectares were planted in cover crops [44]. Extent of cover cropping, however, was not total farm hectarage. Neither vegetable revenue nor farm size was correlated with complexity or diversity of cover crops used. However, negative binomial count data regression of the number of species planted demonstrated that the complexity of cover crop plantings-and their related multifunctional benefits-were linked to the education and experimental nature of farmers. Additionally, farmers were more apt at using cover crops in more complex, multifunctional ways if they knew other farmers that also used cover crops.

\section{Discussion}

Analysis of this survey provides preliminary evidence that Wisconsin's organic vegetable farmers are integrating agroecological practices on their farms, even as growth in the organic market continues to occur. However, the analysis is somewhat simplified and limited in its ability to deal with the full scope and rationale for practice adoption. In addition to economic and farm physical and biological drivers, adoption of any technology, including cover cropping, intertwines with personal values, social norms, available knowledge, and other complex factors, and these factors are challenging to adequately assess in the context of a survey.

This increase in cover crop adoption may be due in part to the implementation of the USDA-NOP regulation in 2002, which encourages use of cover crops as part of organic farmers' nutrient management and soil building strategies, and increased scrutiny of this practice by the certifiers most active in Wisconsin. However, according to survey responses, this does not seem to be the primary driver for increased farmer adoption of cover cropping. In response to the question "I use cover crops because I am supposed to", only $10 \%$ of respondents answered agree, with $0 \%$ ranking strongly agree. The other $90 \%$ of respondents ranked this as neutral, disagree, or strongly disagree. This implies that farmers are using cover crops due to their recognized production and agroecological 
benefits. However, it is important to note that economic pressures imposed by a limited land base may limit farmer's ability to employ cover cropping as an agroecological practice, despite the recognition of their benefits to the management system.

The information collected in the survey further demonstrates varying degrees of complexity and diversity in cover cropping practices, potentially illustrating the desire by farmers to promote a greater degree of agroecosystem services. Respondents used an average of two species every year and three species at least in some years (so, an average of five cover crop species in the farm's portfolio). However, a few farms used highly diverse cover crop selections, with twelve or more total cover crop species in their cover crop portfolios. In terms of specific practices, farmers commonly used mixes of cover crop species in a single field, and many also used overwintering cover crops. Less common were the potentially more management-intensive practices of intercropping and underseeding. Cover cropping complexity also appears to increase when farmers know others using cover crops, which highlights the potential importance of social learning, networking, and farmer-to-farmer education.

Perhaps most interesting, in light of the conventionalization debate, remains the finding that cover crop diversity and complexity was not correlated farm size or revenue. This is counter to the conventionalization argument described previously, which strongly emphasized the growth of organic farm size as a risk factor for conventionalization [79]. Within the context of the organic vegetable industry in California, Guthman [80] posed the argument that when larger vegetable farms continue to farm with agroecological methods, they are unable to compete in the more industrialized market due to its price structure, pushing these farmers toward input substitution approaches and crop specialization. Alternatively, she posits that those farmers operating in alternative markets, such as farmers' markets and Community Support Agriculture, are able to benefit from a structure that rewards diverse crop offerings and provides higher revenue margins, which support the adoption of agroecological practices. While the Wisconsin survey data did not support these trends, it is important to note that these two regions of the USA have substantial differences in other factors that may impact a farmer's choices in farming practices, such as land prices, availability of irrigation water (either rainfed or irrigated), and seasonal costs of inputs. Additionally, overall, the mean and median sizes of farms in Wisconsin, where over $50 \%$ of organic vegetable operations are under 5 hectares in size [81], may be substantially different than those found on the California landscape.

Further research is needed to increase our understanding of the multiple functions of cover crops and the way these functions interact in order to enhance the ability to design agroecological systems. Schipanski et al. [22] advocate for a systems-based approach to cover crop research, integrating knowledge from different disciplines and development of a framework for weighing different management priorities. Increased use of ecological- or bio-economic modeling, which integrates biophysical and socioeconomic data into a single model [82,83], could also be used to assess feasibility and desirability of various cover cropping practices.

\section{Conclusions}

Caution is certainly warranted when extrapolating the results of the assessment presented in this paper, which uses a single practice indicator in organic vegetable systems within a limited region to begin to assess the extent to which organic farmers are employing agroecological practices. Studies conducted across the globe have posed the question of the movement of organic agriculture toward conventionalization and away from its more agroecological foundations [84-87]. From our assessment using cover cropping as a model agroecological indicator, this phenomenon does not appear to be occurring on Wisconsin's organic vegetable farms. It is important to note that many other studies have been conducted from a social science perspective, focused on motivations, scale, and markets, rather than investigating the actual practices employed on organic farms across different size ranges [88]. With a lack of interdisciplinary studies approaching this question from both social and applied production perspectives $[89,90]$, the trends noted by social scientists have not been well-correlated with agronomic practices employed by organic farmers [88]. The ability of organic agriculture to 
scale-up while maintaining agroecological approaches-either as a greater number of farms under the management of the farmer population emerging from a conventional paradigm, or as larger, more specialized farms under a single owner-will be critical to define the role of organic agriculture in the creation of new food systems to sustainably feed the projected 11 billion future global citizens.

Acknowledgments: This research was funded in part by the Wisconsin Agricultural Experiment Station. We also acknowledge Paul Mitchell, Brad Barham, and John Hendrickson in their assistance with survey development and analysis, and all of the farmers who responded to our survey.

Author Contributions: Erin Silva conceived the concept for the paper and wrote the history and parallels of agroecology and organic agriculture movements. Virginia Moore executed the survey and conducted the related analyses. Both authors contributed to the summary and contextualization of cover cropping in an agroecological context, as well as the related discussions and conclusions.

Conflicts of Interest: The authors declare no conflict of interest. The funding sponsor had no role in the design of the study; in the collection, analyses, or interpretation of data; in the writing of the manuscript, and in the decision to publish the results.

\section{References}

1. Wezel, A.; Soldat, V. A quantitative and qualitative historical analysis of the scientific discipline agroecology. Int. J. Agric. Sustain. 2009, 7, 3-18. [CrossRef]

2. Altieri, M.A. Agroecology: The Science of Sustainable Agriculture; Westview Press: Boulder, CO, USA, 1995; p. 433.

3. Francis, C.; Lieblein, G.; Gliessman, S.; Breland, T.A.; Creamer, N.; Harwood, R.; Salomonsson, L.; Helenius, J.; Rickerl, D.; Salvador, R.; et al. Agroecology: The ecology of food systems. J. Sustain. Agric. 2003, 22, 99-118. [CrossRef]

4. Altieri, M.A.; Nicholls, C.I.; Henao, A.; Lana, M.A. Agroecology and the design of climate change-resilient farming systems. Agron. Sustain. Dev. 2015, 35, 869-890. [CrossRef]

5. Lampkin, N.H. Organic Farming; Farming Press: Ipswich, UK, 1990; p. 701.

6. International Federation of Organic Agriculture Movements (IFOAM). Definition of Organic Agriculture. Available online: http://www.ifoam.bio/en/organic-landmarks/definition-organic-agriculture (accessed on 1 October 2016).

7. Méndez, V.E. Agroecology. In Encyclopedia of Geography; Warf, B., Ed.; Sage Publications: Thousand Oaks, CA, USA, 2010; pp. 55-59.

8. Paull, J. The farm as organism: The foundational idea of organic agriculture. Elem. J. Bio-Dyn. Tasmania 2006, 80, 14-18.

9. Drinkwater, L.E. Ecological knowledge: Foundation for sustainable organic agriculture. In Organic Farming: The Ecological System; Francis, C., Ed.; American Society of Agronomy: Madison, WI, USA, 2009; Monograph 54; pp. 19-48.

10. Frost, D. Deconstructing the Organic Movement. In UK Organic Research 2002: Proceedings of the COR Conference; Powell, J., Ed.; University of Wales Aberystwyth: Aberystwyth, UK, 2002; pp. 113-114.

11. De Abreu, L.S.; Lamine, C.; Bellon, S. Trajetórias da Agroecologia no Brasil: Entre Movimentos Sociais, Redes Científicas e Políticas Públicas. Available online: http://www.aba-agroecologia.org.br/revistas/index.php/ rbagroecologia/article/view/8346/5922 (accessed on 1 October 2016).

12. Wezel, A.; Casagrande, M.; Celette, F.; Vian, J.-F.; Ferrer, A.; Peigné, J. Agroecological practices for sustainable agriculture. A review. Agron. Sustain. Dev. 2014, 34, 1-20. [CrossRef]

13. Gliessman, S.R. Agroecology: Ecological Processes in Sustainable Agriculture; Ann Arbor Press: Chelsea, MI, USA, 1998; p. 357.

14. U.S. Government Publishing Office. Electronic Code of Federal Regulations. Available online: http:/ / www.ecfr.gov/cgi-bin/text-idx?c=ecfr\&sid=3f34f4c22f9aa8e6d9864cc2683cea02\&tpl=/ecfrbrowse/ Title07/7cfr205_main_02.tpl (accessed on 1 October 2016).

15. Buck, D.; Getz, C.; Guthman, J. From farm to table: The organic vegetable commodity chain of northern California. Sociol. Rural. 1997, 37, 3-20. [CrossRef]

16. Hall, A.; Mogyorody, V. Organic Farmers in Ontario: An examination of the conventionalisation argument. Sociol. Rural. 2001, 41, 399-422. [CrossRef] 
17. Dabney, S.M. Cover crop impacts on watershed hydrology. J. Soil Water Conserv. 1998, 53, 207-213.

18. Tonitto, C.; David, M.B.; Drinkwater, L.E. Replacing bare fallows with cover crops in fertilizer-intensive cropping systems: A meta-analysis of crop yield and N dynamics. Agric. Ecosyst. Environ. 2006, 112, 58-72. [CrossRef]

19. Lundgren, J.G.; Fergen, J.K. Enhancing predation of a subterranean insect pest: A conservation benefit of winter vegetation in agroecosystems. Appl. Soil Ecol. 2011, 51, 9-16. [CrossRef]

20. Ryan, M.R.; Mirsky, S.B.; Mortensen, D.A.; Teasdale, J.R.; Curran, W.S. Potential synergistic effects of cereal rye biomass and soybean planting density on weed suppression. Weed Sci. 2011, 59, 238-246. [CrossRef]

21. Schipanski, M.E.; Drinkwater, L.E. Nitrogen fixation of red clover interseeded with winter cereals across a management-induced fertility gradient. Nutr. Cycl. Agroecosyst. 2011, 90, 105-119. [CrossRef]

22. Schipanski, M.E.; Barbercheck, M.; Douglas, M.R.; Finney, D.M.; Haider, K.; Kaye, J.P.; Kemanian, R.; Mortensen, D.A.; Ryan, M.R.; Tooker, J.; et al. A framework for evaluating ecosystem services provided by cover crops in agroecosystems. Agric. Syst. 2014, 125, 12-22. [CrossRef]

23. Altieri, M.A.; Funes, F.; Petersen, P. Agroecologically efficient agricultural systems for smallholder farmers: Contributions to food sovereignty. Agron. Sustain. Dev. 2012, 32, 1-13. [CrossRef]

24. Abdollahi, L.; Munkholm, L.J. Tillage system and cover crop effects on soil quality: Chemical, mechanical, and biological properties. Soil Sci. Soc. Am. J. 2014, 78, 262-270.

25. Blanco-Canqui, H.; Claassen, M.M.; Presley, D.R. Summer cover crops fix nitrogen, increase crop yield, and improve soil-crop relationships. Agron. J. 2012, 104, 137-147. [CrossRef]

26. Chen, G.; Weil, R.R. Root growth and yield of maize as affected by soil compaction and cover crops. Soil Tillage Res. 2011, 117, 17-27. [CrossRef]

27. Calonego, J.; Rosolem, C. Soybean root growth and yield in rotation with cover crops under chiseling and no-till. Eur. J. Agron. 2010, 33, 242-249. [CrossRef]

28. Cruz, J.L.; da Silva Souza, L.; dos Santos de Souza, N.C.; Pelacani, C.R. Effect of cover crops on the aggregation of a soil cultivated with papaya (Carica papaya L.). Sci. Hortc. 2014, 172, 82-85. [CrossRef]

29. Hermawan, B.; Bomke, A.A. Effects of winter cover crops and successive spring tillage on soil aggregation. Soil Till. Res. 1997, 44, 109-120. [CrossRef]

30. Alliaume, F.; Rossing, W.A.H.; Tittonell, P.; Jorgea, G.; Dogliotti, S. Reduced tillage and cover crops improve water capture and reduce erosion of fine textured soils in raised bed tomato systems. Agric. Ecosyst. Environ. 2014, 183, 127-137. [CrossRef]

31. Mailapalli, D.R.; Horwath, W.R.; Wallender, W.W.; Burger, M. Infiltration, runoff, and export of dissolved organic carbon from furrow-irrigated forage fields under cover crop and no-till management in the arid climate of California. J. Irrig. Drain Eng. 2012, 138, 35-42. [CrossRef]

32. Folorunso, O.A.; Rolston, D.E.; Prichard, T.; Louie, D.T. Soil surface strength and infiltration rate as affected by winter cover crops. Soil Technol. 1992, 25, 189-197. [CrossRef]

33. Silva, E.M. Screening five fall-sown cover crops for use in organic no-till crop production in the Upper Midwest. Agroecol. Sustain. Food Syst. 2014, 38, 748-763. [CrossRef]

34. Villamil, M.B.; Bollero, G.A.; Darmody, R.G.; Simmons, F.W.; Bullock, D.G. No-till corn/soybean systems including winter cover crops: Effects on soil properties. Soil Sci. Soc. Am. J. 2006, 70, 1936-1944. [CrossRef]

35. Sainju, U.M.; Whitehead, W.F.; Singh, B.R. Cover crops and nitrogen fertilization effects on soil aggregation and carbon and nitrogen pools. Can. J. Soil Sci. 2003, 83, 155-165. [CrossRef]

36. Nascente, A.S.; Li, Y.C.; Crusciol, C.A.C. Cover crops and no-till effects on physical fractions of soil organic matter. Soil Tillage Res. 2013, 130, 52-57. [CrossRef]

37. Ding, G.; Liu, X.; Herbert, S.; Novak, J.; Amarasiriwardenae, D.; Xing, B. Effect of cover crop management on soil organic matter. Geoderma 2006, 30, 229-239. [CrossRef]

38. Collins, H.P.; Delgado, J.A.; Alva, A.K.; Follett, R.E. Use of nitrogen-15 isotopic techniques to estimate nitrogen cycling from a mustard cover crop to potatoes. Agron. J. 2007, 99, 27-35. [CrossRef]

39. Abdul-Baki, A.A.; Teasdale, J.R.; Korcak, R.F. Nitrogen requirements of fresh- market tomatoes on hairy vetch and black polyethylene mulch. HortScience 2007, 32, 217-221.

40. Schutter, M.E.; Dick, R.P. Microbial community profiles and activities among aggregates of winter fallow and cover-cropped soil. Soil Sci. Soc. Am. J. 2002, 66, 142-153. [CrossRef]

41. Buyer, J.S.; Teasdale, J.R.; Roberts, D.P.; Zasada, I.A.; Maul, J.E. Factors affecting soil microbial community structure in tomato cropping systems. Soil Biol. Biochem. 2010, 42, 831-841. [CrossRef] 
42. Lehman, R.M.; Taheria, W.T.; Osborne, S.L.; Buyer, J.S.; Douds, D.D., Jr. Fall cover cropping can increase arbuscular mycorrhizae in soils supporting intensive agricultural production. Appl. Soil Ecol. 2012, 61, 300-304. [CrossRef]

43. De Baets, S.; Poesen, J.; Meersmans, J. Cover crops and their erosion-reducing effects during concentrated flow erosion. Catena 2011, 85, 237-244. [CrossRef]

44. Kaspar, T.C.; Radke, J.K.; Laflen, J.M. Small grain cover crops and wheel traffic effects on infiltration, runoff, and erosion. J. Soil Water Conserv. 2001, 56, 160-164.

45. Ryder, M.H.; Fares, A. Evaluating cover crops for use as vegetative filters to control sediment and nutrient loading from agricultural runoff in a Hawaiian watershed. J. Am. Water Res. Assoc. 2008, 44, 640-653. [CrossRef]

46. Kaspar, T.C.; Jaynes, D.B.; Parkin, T.B.; Moorman, T.B.; Singer, J.W. Effectiveness of oat and rye cover crops in reducing nitrate losses in drainage water. Agric. Water Manag. 2012, 110, 25-33. [CrossRef]

47. Heinrich, A.; Smith, R.; Cahn, M. Winter-killed cereal rye cover crop influence on nitrate leaching in intensive vegetable production systems. HortTechnology 2014, 24, 502-511.

48. Wyland, L.; Jackson, L.; Chaney, W.; Klonsky, K.; Koike, S.; Kimple, B. Winter cover crops in a vegetable cropping system: Impacts on nitrate leaching, soil water, crop yield, pests and management costs. Ecosyst. Environ. 1996, 59, 1-17. [CrossRef]

49. Kunz, C.; Sturm, D.J.; Varnholt, D.; Walker, F.; Gerhards, R. Allelopathic effects and weed suppressive ability of cover crops. Plant Soil Environ. 2016, 62, 60-66.

50. Brust, J.; Claupein, W.; Gerhards, R. Growth and weed suppression ability of common and new cover crops in Germany. Crop Prot. 2014, 63, 1-8. [CrossRef]

51. Björkman, T.; Lowry, C.; Shail, J.W., Jr.; Brainard, D.C.; Anderson, D.S.; Masiunas, J.B. Mustard cover crops for biomass production and weed suppression in the Great Lakes Region. Agron. J. 2015, 107, 1235-1249. [CrossRef]

52. Ellis, K.E.; Barbercheck, M.E. Management of Overwintering Cover Crops Influences Floral Resources and Visitation by Native Bees. Environ. Entomol. 2015, 44, 999-1010. [CrossRef] [PubMed]

53. Ponti, L.; Altieri, M.A.; Gutierrez, A.P. Effects of crop diversification levels and fertilization regimes on abundance of Brevicoryne brassicae (L.) and its parasitization by Diaeretiella rapae (M'Intosh) in broccoli. Agric. For. Entomol. 2007, 9, 209-214. [CrossRef]

54. Aguilar-Fenollosa, E.; Ibáñez-Gual, M.V.; Pascual-Ruiz, S.; Hurtado, M.; Jacas, J.A. Effect of ground-cover management on spider mites and their phytoseiid natural enemies in clementine mandarin orchards (I): Bottom-up regulation mechanisms. Biolog. Control 2011, 59, 158-170. [CrossRef]

55. Wang, Q.; Li, Y.; Klassen, W.; Handoo, Z. Influence of cover crops and soil amendments on okra (Abelmoschus esculentus L.) production and soil nematodes. Renew. Agric. Food Syst. 2006, 22, 41-53. [CrossRef]

56. Viaene, N.M.; Abawi, G.S. Management of Meloidogyne hapla on lettuce in organic soil with sudangrass as a cover crop. Plant Dis. 1998, 82, 945-952. [CrossRef]

57. Butler, D.M.; Rosskopf, E.N.; Kokalis-Burelle, N.; Albano, J.P.; Muramoto, J.; Shennan, C. Exploring warm-season cover crops as carbon sources for anaerobic soil disinfestation (ASD). Plant Soil 2012, 355, 149-165. [CrossRef]

58. Scholberg, J.M.; Dogliotti, S.; Leoni, C.; Cherr, C.M.; Zotarelli, L.; Rossing, W.A. Cover Crops for Sustainable Agrosystems in the Americas. In Genetic Engineering, Biofertilisation, Soil Quality and Organic Farming, 4th ed.; Lichtfouse, Ed.; Springer: New York, NY, USA; pp. 23-58.

59. Lu, Y.-C.; Watkins, K.B.; Teasdale, J.R.; Abdul-Baki, A.A. Cover crops in sustainable food production. Food Rev. Intern. 2000, 16, 121-157. [CrossRef]

60. Reicosky, D.; Forcella, F. Cover crop and soil quality interactions in agroecosystems. J. Soil Water Conserv. 1998, 53, 224-229.

61. Carrera, L.M.; Abdul-Baki, A.A.; Teasdale, J.R. Cover crop management and weed suppression in no-tillage sweet corn production. HortScience 2004, 39, 1262-1266.

62. Creamer, N.G.; Bennett, M.A.; Stinner, B.R.; Cardina, J. A comparison of four processing tomato production systems differing in cover crop and chemical inputs. J. Am. Soc. Hortc. Sci. 1996, 121, 559-568.

63. Ess, D.; Vaughan, D.; Luna, J.; Sullivan, P. Energy and economic savings from the use of legume cover crops in Virginia corn production. Am. J. Altern. Agric. 1994, 9, 178-185. [CrossRef] 
64. Frye, W.; Smith, W.; Williams, R. Economics of winter cover crops as a source of nitrogen for no-till corn. J. Soil Water Conserv. 1985, 40, 246-249.

65. Langdale, G.; Blevins, R.; Karlen, D.; McCool, D.; Nearing, M.; Skidmore, E.; Thomas, A.; Tyler, D.; Williams, J. Cover crop effects on soil erosion by wind and water. In Cover Crops for Clean Water; Hargrove, W., Ed.; Soil and Water Conservation Society; West Tennessee Experiment Station: Jackson, TN, USA, 1991; pp. 141-145.

66. Gabriel, J.L.; Garrido, A.; Quemada, M. Cover crops effect on farm benefits and nitrate leaching: Linking economic and environmental analysis. Agric. Syst. 2013, 121, 23-32. [CrossRef]

67. Meisinger, J.; Hargrove, W.; Mikkelsen, R.; Williams, J.; Benson, V. Effects of cover crops on groundwater quality. In Cover Crops for Clean Water; Hargrove, W., Ed.; Soil and Water Conservation Society; West Tennessee Experiment Station: Jackson, TN, USA, 1991; pp. 57-68.

68. Sharpley, A.; Smith, S. Effects of cover crops on surface water quality. In Cover Crops for Clean Water; Hargrove, W., Ed.; Soil and Water Conservation Society; West Tennessee Experiment Station: Jackson, TN, USA, 1991; pp. 41-49.

69. Bjorkman, T.; Shail, J.W. Using a buckwheat cover crop for maximum weed suppression after Early vegetables. HortTechnology 2013, 23, 575-580.

70. Altieri, M.A.; Nicholls, C.I. Biodiversity and Pest Management in Agroecosystems, 2nd ed.; Howarth Press: Binghamton, NY, USA, 2004; p. 252.

71. Ajzen, I. The theory of planned behavior. Organ. Behav. Hum. Decis. Proc. 1991, 50, 179-211. [CrossRef]

72. Bland, W.L.; Bell, M.M. A holon approach to agroecology. Int. J. Agric. Sustain. 2007, 5, 280-294.

73. Mariola, M.; Miller, M.; Hendrickson, J. Organic Agriculture in Wisconsin: 2003 Status Report. Available online: http://www.cias.wisc.edu/wp-content/uploads/2008/07/org113.pdf (accessed on 1 October 2016).

74. Carusi, C.E.; Gurda, A.; McNair, R.; Pfeiffer, A.; Silva, E.M. Organic Agriculture in Wisconsin: 2014 Status Report. Available online: http://www.cias.wisc.edu/wp-content/uploads/2015/02/ ciasorganicreport2015final041615.pdf (accessed on 1 October 2016).

75. Silva, E.M.; Dong, F.; Mitchell, P.D.; Hendrickson, J. Impact of marketing channels on perceptions of quality of life and profitability of Wisconsin's organic vegetable farmers. Renew. Agric. Food Syst. 2014, 30, 428-438. [CrossRef]

76. Moore, V.M.; Mitchell, P.D.; Silva, E.M.; Barham, B. Cover Crop Adoption and Intensity on Wisconsin's Organic Vegetable Farms. Agroecol. Sustain. Food Syst. 2016, 40, 693-713. [CrossRef]

77. Dillman, D.A.; Smyth, J.D.; Christian, L.M. Internet, Mail, and Mixed-Mode Surveys: The Tailored Design Method, 3rd ed.; John Wiley \& Sons, Inc.: Hoboken, NJ, USA, 2009; pp. 15-41.

78. Darnhofer, I.; Lindenthal, T.; Bartel-Kratochvil, R.; Zollitsch, W. Conventionalisation of organic farming practices: From structural criteria towards an assessment based on organic principles. A review. Agron. Sustain. Dev. 2010, 30, 67-81. [CrossRef]

79. Guthman, J. Regulating meaning, appropriating nature: the codification of California organic agriculture. Antipode 1998, 30, 135-154. [CrossRef]

80. Lyon, A.; Silva, E.M.; Bell, M.; Zystro, J. Seed and plant breeding for Wisconsin's organic vegetable sector: Understanding farmers' needs and practices. Agroecol. Sustain. Food Syst. 2015, 39, 601-624. [CrossRef]

81. Hazell, P.; Wood, S. From science to technology adoption: the role of policy research in improving natural resource management. Agric. Ecosyst. Environ. 2000, 82, 385-393. [CrossRef]

82. Watzold, F.; Drechsler, M.; Armstrong, C.W.; Baumgartner, S.; Grimm, V.; Huth, A.; Perrings, C.; Possingham, H.P.; Shogren, J.F.; Skonhoft, A.; et al. Ecological-economic modeling for biodiversity management: Potential, pitfalls, and prospects. Conserv. Biol. 2006, 20, 1034-1041. [CrossRef] [PubMed]

83. Allen, P.; Kovach, M. The capitalistic composition of organic: The potential of markets in fulfilling the promise of organic agriculture, Agric. Hum. Values 2000, 17, 221-232. [CrossRef]

84. Alrøe, H.; Noe, E. What makes organic agriculture move: Protest, meaning or market? A polyocular approach to the dynamics and governance of organic agriculture. Int. J. Agric. Resour. Gov. Ecol. 2008, 7, 5-22. [CrossRef]

85. DeLind, L.B. Transforming organic agriculture into industrial organic products: Reconsidering nationalorganic standards. Hum. Organ. 2000, 59, 198-208. [CrossRef] 
86. Flaten, O.; Lien, G.; Ebbesvik, M.; Koesling, M.; Valle, P.S. Do the new organic producers differ from the 'old guard'? Empirical results from Norwegian dairy farming. Renew. Agric. Food Syst. 2006, 21, 174-182. [CrossRef]

87. Guptill, A. Exploring the conventionalization of organic dairy: Trends and counter-trends in upstate New York. Agric. Hum. Values 2009, 26, 29-42. [CrossRef]

88. De Wit, J.; Verhoog, H. Organic values and the conventionalization of organic agriculture. NJAS Wagening. J. Life Sci. 2007, 54, 449-462. [CrossRef]

89. Watson, C.; Walker, R.; Stockdale, E. Research in organic production systems-Past, present and future. J. Agric. Sci. 2008, 146, 1-19. [CrossRef]

90. Lamine, C.; Bellon, S. Conversion to organic farming: A multidimensional research object at the crossroads of agricultural and social sciences. A review. Agron. Sustain. Dev. 2009, 29, 97-112. [CrossRef]

(C) 2016 by the authors; licensee MDPI, Basel, Switzerland. This article is an open access article distributed under the terms and conditions of the Creative Commons Attribution (CC-BY) license (http://creativecommons.org/licenses/by/4.0/). 